Our Nature (2011) 9

\title{
Ethno-botanical and Germinational Aspects of Rauvolfia serpentina (L.) Benth. ex Kurz
}

\author{
M.P. Trivedi" and R. Kumari \\ Department of Botany, Patna Science College, Patna University, Patna-5 \\ "E-mail: mptrivedi1956@rediffmail.com
}

Received: 22.04.2011, Accepted: 15.12.2011

Key words: Ethnobotany, germination, Rauvolfia serpentina.

Rauvolfia serpentina is a medicinal plant of family Apocynaceae. For centuries since pre-Vedic period it has been used for different medicinal purposes in India and Malaysia. Its preparations have been reported for treatment of fever, snake bite and insanity.

The plant is distributed widely in subHimalayan tract from Punjab eastward to Nepal, Sikkim and Bhutan, Assam, lower hills of Gangetic plains, Eastern and Western Ghats, Central India and in the Andamans.

Fruit is drupe, polished green in young stage and purplish black at maturity. It is slightly connate and obliquely ovoid and is found in bunch depending upon height and healthiness of plant. The bark is pale brown and corky with irregular longitudinal fissures on it. Seeds have smooth but extremely hard seedcoat surface. Unscarified seeds of this species have very poor germination (Trivedi and Kumari, 2009). This paper deals with germination behaviour and ethnobotanical aspects of $R$. serpentina.

Seeds were collected from Falka of Katihar and Purnea districts. Local persons were interviewed about its ethnobotanical aspects. For germination seeds were mechanically scarified with blade and half coats were removed. Care was taken to protect the embryonal portion. Germination was achieved after treating the seeds with $0.1 \% \mathrm{HgCl}_{2}$ and washed with distilled water and putting them on moist filter paper backed with cotton wool in petridishes. Distilled water was used for moistening. The temperature maintained was $35^{\circ} \mathrm{C}$. In moisture stress experiments, artificial stress was created by increasing the number of filter papers keeping the amount of water constant (Sinha et al., 1991). IAA, GA and Cytokinins were used in 10, 25, 50 and 100 ppm concentrations.

\section{Ethnobotanical uses}

Dried root bark powder is used against insomnia, Schizophrenia or violent mental disorders. Local tribes of Falka (Bihar) use $R$. serpentina root and leaves to treat snake bites. Its freshly ground leaves when applied to the toe serve as an antidote for snake poison. Some people of Jalalgarh of Purnea district (Bihar) think that snakes do not come closer around 20-25 ft. distance surrounding this plant.

\section{Germination potential}

The seed coat is hard and seeds showed seedcoat dormancy. Unscarified seeds did not germinate at all while freshly harvested 
Our Nature (2011) 9

Table 1. Effect of moisture stress on seed germination of $R$. serpentina.

\begin{tabular}{lccc}
\hline Moisture regimes & Initiation period (days) & Rate of germination/ day (\%) & $\%$ of germination \pm SE \\
\hline Regime I & 1 & 39.2 & $54.0 \pm 2.66$ \\
Regime II & 1 & 28.6 & $33.3 \pm 3.23$ \\
Regime III & 1 & 24.9 & $33.3 \pm 3.23$ \\
Regime IV & 6 & 13.9 & $16.7 \pm 3.20$ \\
Regime V & 2 & 5.6 & $5.6 \pm 3.21$ \\
\hline
\end{tabular}

Table 2. Effect of photoperiod on germination responses of $R$. serpentina.

\begin{tabular}{lccc}
\hline \multirow{2}{*}{ Photo periods } & Initiation period (days) & Rate of germination/day (\%) & $\%$ of germination \pm SE \\
\cline { 2 - 4 } & $\boldsymbol{R}$. serpentina & $\boldsymbol{R}$. serpentina & $\boldsymbol{R}$. serpentina \\
\hline $8 \mathrm{hr} \mathrm{L} / 16 \mathrm{hr} \mathrm{D}$ & 2 & 46.7 & $85.0 \pm 2.89$ \\
$12 \mathrm{hr} \mathrm{L} / 12 \mathrm{hr}$ D & 3 & 26.0 & $35.0 \pm 2.89$ \\
$16 \mathrm{hr} \mathrm{L} / 8 \mathrm{hr}$ D & 2 & 25.0 & $40.0 \pm 2.89$ \\
\hline
\end{tabular}

Table 3. Effect of growth regulators on germination responses of $R$. serpentina.

\begin{tabular}{|c|c|c|c|c|c|c|c|}
\hline \multirow{2}{*}{$\begin{array}{l}\text { Concentration of } \\
\text { hormone (ppm) }\end{array}$} & \multirow{2}{*}{$\begin{array}{c}\text { Initiation } \\
\text { period } \\
\text { (days) }\end{array}$} & \multicolumn{3}{|c|}{ Rate of germination/day (\%) } & \multicolumn{3}{|c|}{$\%$ of germination $\pm \mathrm{SE}$} \\
\hline & & IAA & $\begin{array}{c}\text { Gibberellic } \\
\text { acid }\end{array}$ & Cytokinin & IAA & $\begin{array}{c}\text { Gibberellic } \\
\text { acid }\end{array}$ & Cytokinin \\
\hline Contro & 1 & 39.2 & 39.2 & 39.2 & 54.0 & $54.0 \pm 2.66$ & 66 \\
\hline 10 & 1 & 73.7 & 72.5 & 72.5 & $95.2 \pm 2.77$ & 48 & .74 \\
\hline 25 & 1 & 61.1 & 76.8 & 76.8 & $76.0 \pm 2.77$ & $51.6 \pm 2.48$ & $95.2 \pm 2.77$ \\
\hline 50 & 1 & 71.9 & 71.9 & 71.9 & $85.7 \pm 2.20$ & $60.2 \pm 2.48$ & $90.4 \pm 2.74$ \\
\hline 100 & 1 & 69.5 & 82.7 & 82.7 & $90.4 \pm 2.74$ & $77.4 \pm 2.48$ & $95.2 \pm 2.77$ \\
\hline
\end{tabular}

scarified seeds (seed coat partially removed by blade) showed $54 \%$ germination. Scarification by conc. $\mathrm{H}_{2} \mathrm{SO}_{4}$ for 2-20 min was of no use. Seeds in response to moisture stress established that availability of water is directly proportional to seed germination (Khadeer et al., 1987, Agarwal et al., 1999) (Tab. 1). In scarified seeds $8 \mathrm{hL} / 16 \mathrm{hD}$ enhanced germination up to $85.0 \%$ (Tab. 2). Ahmad and Bano (2007) have reported induced germination in dormant seeds of orange fruited plant Solanum nigrum due to appropriate photoperiods. In response to growth regulators, the scarified seeds showed $95.2 \%$ germination at $25 \mathrm{ppm}$ and $100 \mathrm{ppm}$ of cytokinin, $90.4 \%$ at $100 \mathrm{ppm}$ at IAA and $77.4 \%$ at same concentration of gibberellic acid (Tab. 3). According to Srivastava (2005), the promotive effect of all these hormones in scarified seeds is due to induction of enzyme activity, membrane permeability and nucleic acid directed protein synthesis.

\section{Acknowledgements}

The authors are thankful to Prof. U.K. Sinha, Head, Department of Botany, Patna University for providing the laboratory facilities.

\section{References}

Agarwal, R.M., R. Pandey and S. Gupta 1999. Certain aspects of water stress induced changes and tolerance mechanisms in plants. J. Ind. Bot. Soc. 78: 255-269.

Ahmad, M.S. and Y. Bano 2007. Effect of red light on seed dormancy of orange fruited plant of Solanum nigrum. Int. J. Mendel 24(3-4): 101.

Khadeer, M.A., E. Seshagiri and S.Y. Anwar 1987. Evaluation of the role of ascorbic acid in salt tolerance with different varieties of safflower (Carthamus tinctorius L.). Mendel 4(4): 225-228.

Sinha, R.P., A.K. Mishra and M.P. Trivedi 1991. Seed dormancy and germination in Melilotus spp. In: Recent researches in ecology, environment and 


\section{Our Nature (2011) 9}

pollution (Eds. R.N. Trivedi, P.K. Sen Sharma and M.P. Singh).Today and Tomorrow's Printers and Publishers, New Delhi-5. 5: 203-214.

Srivastava, H.S. 2005. Plant physiology. Rastogi Publications, Meerut.
Trivedi, M.P. and R. Kumari 2009. Germination potential of Rauvolfia serpentina in varying environmental regimes. J. Indian bot. Soc. $88(3-$ 4): $58-61$. 